\title{
Cholinergic and anticholinesterase activities of total protein extract of Morinda morindoüdes on isolated rabbit duodenum
}

\author{
Abiba Ouattara GBOKO ${ }^{1 *}$, Souleymane MEITE ${ }^{1,2}$, Calixte BAHI ${ }^{1}$, \\ Jean David N'GUESSAN ${ }^{1}$, Joseph Allico DJAMAN ${ }^{1}$ and Adama COULIBALY ${ }^{1}$ \\ ${ }^{1}$ Laboratoire de Pharmacodynamie Biochimique, UFR Biosciences, Université de Cocody-Abidjan, \\ 22 BP 582 Abidjan 22, Côte d'Ivoire. \\ ${ }^{2}$ Biochimical Laboratory of Pasteur Institute of Côte d'Ivoire, P.O. Box 490, Abidjan 22, Côte d'Ivoire. \\ *Corresponding author: E-mail: gbokoabiba@yahoo.fr. Tel (00225)08134444.
}

\begin{abstract}
Traditional herbal medicines such as Morinda morindoïdes are used for treatment of intestinal disorders including constipation in Ivory Coast. The aim of present study was to investigate the effect of total protein of Morinda morindoïdes extract (PT-Mm) on rabbit duodenum contractility and the involved possible mechanism(s). PT-Mm was extracted according to the saturation method of Dawson with ammonium sulfate. The cholinergic effect of the extract was determined by the in vitro organ bath method. The acetylcholinesterase (AChE) extracted from rabbit duodenum and it activity was determined by Ellman's assay using acetylthiocholine (ASCh) as substrate. PT-Mm concentrations $(40,80,120$ and $200 \mu \mathrm{g} / \mathrm{mL})$ showed dose-dependent effect a both tonicity and amplitude of the duodenum spontaneous contractions. The effective concentration which induces $50 \%$ effect of PT-Mm $\left(\mathrm{EC}_{50}\right)$ was obtained with $68.57 \pm 0.89 \mu \mathrm{g} / \mathrm{mL}$. The antagonist tests carried out showed a considerable reduction (90\%) in the amplitudes of duodenal contractions in the presence of atropine, but with nifedipine, the contractions were completely inhibited. PT-Mm also exerted non-competitive inhibition on $\mathrm{AChE}\left(\mathrm{Vmax}=5687 \mathrm{mM} / \mathrm{min}\right.$ and $\left.\mathrm{K}_{\mathrm{M}}=578 \mu \mathrm{M}\right)$. These results suggest that PT-Mm could stimulate duodenum smooth muscle contraction because it contains anti-AChE and cholinomimetic substances which, through muscarinic receptors, increase $\mathrm{Ca}^{2+}$ mobilization from extracellular. Therefore, PT-Mm could be used as a laxative, due to its stimulating effects on duodenal contractility.

(C) 2012 International Formulae Group. All rights reserved.
\end{abstract}

Keywords: Morinda morindoides, acetylcholinesterase, duodenum, contraction.

\section{INTRODUCTION}

Many people nowadays turn to the use of natural products for treatment of gastrointestinal disorders including diarrhoea, indigestion and constipation (Ragone et al., 2007). Constipation is a highly prevalent often chronic gastro-intestinal disorder that affects adults (Bosshard et al., 2004; Muller-Lissner, 2009). Natural products have served as a source of medicine for centuries and about half of the pharmaceuticals in use today are derived from natural products (Ginsburg and Deharo, 2011). Dependance on plants as the source of medicines is prevalent in developing 
countries where traditional medicine plays a major role in health care (Azam et al., 2011).

Morinda morindoïdes (baker) Miln-

Redh (Rubiaceae) is well known in the traditional medicine practice of tropical countries. In the Democratic Republic of Congo, M. morindoïdes has long been used in villages and towns in the treatment of some parasitic diseases, and the leaf extracts of the plant have been shown to possess antiprotozoal activity particularly against Entamoeba histolytica and rheumatic pains (Cimanga et al., 2003; Cimanga et al., 2006). In Ivory Coast, Morinda morindö̈des is used as an antifungal agent and to treat diarrhoea (Meite et al., 2009). Recently Zirihi et al. (2005) showed the activity of the ethanol extract of $M$. morindoïdes against chloroquine-resistant FcB1/Colombia strain of Plasmodium falciparum. Also, ten flavonoids and eight iridoid glycosides have been isolated from the butanol and ethyl acetate fractions by Cimanga et al. (1999). Some interesting biological activities related to some of its traditional uses, including antioxidative (Cimanga et al., 1999), cardioinhibitory (N'Guessan et al., 2002), anticomplementary (Cimanga et al., 2003), antiamoebic (Cimanga et al., 2006), immunologic (Mankele et al., 2006), antimalarial (Cimanga et al., 2008) and spasmolytic (Cimanga et al., 2010) activities were previously reported. The present work was planned to examine in vitro the laxative activity of total protein extract of Morinda morindoides and its mechanism on duodenal smooth muscle contractility.

\section{MATERIALS AND METHODS}

\section{Plant materiel}

The leaves of Morinda morindoïdes (Rubiaceae) were collected from Daloa (central west region of Ivory Coast) in June 2009. The plant was identified and authenticated by Pr Ake Assi of the
Department of Botany, University of Cocody. A voucher specimen (no 17710) of the plant was deposited in the herbarium of the National Floristic Center of the University of Cocody-Abidjan.

\section{Animals}

Rabbits of both sexes, 12-16 weeks old, weighing $1.5-2 \mathrm{~kg}$ and bred at the Department of Biosciences, (University of CocodyAbidjan), were used for the experiments. All animals were kept at constant humidity $(60 \%)$ and temperature $\left(25^{\circ} \mathrm{C}\right)$ in a 12- hour light / dark cycle. They had free access to food and water.

The animals were cared for and treated according to the principles for using of laboratory animals, and approval for the studies was given by the ethical committee of the University of Cocody- Abidjan. The equipment, handling and sacrificing of the animals were in accordance with the European Council legislation 87/609/EEC for the protection of experimental animals (Mitjans et al., 2008). Before the experiment rabbits were deprived from food for $24 \mathrm{~h}$ but had free access to water.

\section{Drugs and chemicals}

The drugs used were: atropine, nifedipine, DTNB, acetylthiocholine and ammonium sulfate. All chemicals were purchased from Sigma Chemicals Co. (St Louis, MQ, USA), Aldrich Chemical Co. (Steineheim, Germany), and Merck (Darmstadt, Germany).

\section{Preparation of PT-Mm}

M. morindoïdes leaves were cleaned of extraneous matter, air-dried at room temperature for 7 days and ground into a fine powder. The powder was mixed with distilled water ( $80 \mathrm{~g}$ of powder in $2 \mathrm{~L}$ of distilled water) for $24 \mathrm{~h}$ with constant stirring. The 
extract was filtered twice through cotton wool, then through Whatman filter paper (No.1).

The filtrate is saturated with ammonium sulfate to $90 \%$ saturation according to the method of Dawson et al. (1986) for the precipitation of protein. After homogenization, the solution was kept for 24 hours and subsequently centrifuged 4000 trs/min. A fraction that was obtained showed two phases: an upper phase (supernatant) and a lower phase (the sediment) which was our protein extract. The sediment collected was dialyzed against distilled water (Wilson and Walker, 1994), with a synthetic membrane of dialysis. The presence of protein in the dialyzed pellet was revealed by the Lowry test (Lowry et al., 1951). Protein solution was freeze-dried for better storage stability (Osterlund and Janson, 1997) and the resulting powder was our total proteins extract of Morinda morindoides leaves (PT-Mm).

\section{Duodenum tissue preparation}

On the day of experiment, rabbits were sacrificed by a sharp blow on the neck. After a median laparotomy, duodenal muscle strips (2 $\mathrm{cm}$ ) were dissected and mounted in an organ bath containing Tyrode solution (100 mL) between two stainless steel hooks vertically. The lower hook was fixed at the bottom of the organ bath and the upper one was connected to an isotonic transducer (Harvard transducer, UK) connected to a recorder (Harvard Universal Oscillograph, UK). The Tyrode solution composition ( $\mathrm{pH} 7.4$ and $37{ }^{\circ} \mathrm{C}$ ) was (in $\mathrm{mM}$ ): $\mathrm{NaCl}$ (130.5); $\mathrm{KCl}$ (5.63); $\mathrm{CaCl}_{2}$ (2.16); $\quad \mathrm{MgCl}_{2}$ (0.24); $\mathrm{NaH}_{2} \mathrm{PO} 4$ (1.18); $\mathrm{NaHCO}_{3}$ (11.90) and glucose (11.10) which was continuously bubbled with air (Madeira et al., 2002). The initial tension was $1 \mathrm{~g}$ throughout the experiment and equilibrium period was $30 \mathrm{~min}$. After equilibrium period spontaneous contractions were recorded for 5 min in the absence (control) or presence of increasing doses $(40 \mu \mathrm{g} / \mathrm{mL}$ to $200 \mu \mathrm{g} / \mathrm{mL})$ of PT-Mm. Each test was repeated three times and duodenum strip was washed 2-3 times with the Tyrode solution in order to avoid the cumulative effects of products. Antagonist tests with atropine and nifedipine were made at the concentration for which these substances have no effect on the contractile activity of rabbit duodenum. Thus, different doses of antagonist were assessed on contractile activity of duodenal smooth muscle in the presence of PT-Mm.

\section{In vitro analysis of $\mathrm{AChE}$ activity}

Enzyme extraction was performed according to the method of Khoa and Ochillo (1987). A length of duodenum weighing $1 \mathrm{~g}$ was added to $50 \mathrm{~mL}$ phosphate buffer and crushed with a mortar (Ultra Turax T 25). The homogenate was centrifugated and the supernatant was used for the assays. The AChE activity was determined in vitro by Ellman et al. (1961) method. The assay contained a mixture of $100 \mu \mathrm{L}$ of 5,5' - dithiobis-(2-nitro) benzoic acid (DTNB) (0.01 M) and $25 \mu \mathrm{L}$ of acetylthiocholine (ASCh) of varying concentrations in $50 \mathrm{mM}$ potassium phosphate buffer, $\mathrm{pH}$ 7.8, followed by the addition of $75 \mu \mathrm{L}$ AChE in $50 \mathrm{mM}$ potassium phosphate buffer, $\mathrm{pH}$ 7.8. The enzymatic reaction was initiated at $25{ }^{\circ} \mathrm{C}$ and the absorbance change was monitored at $412 \mathrm{~nm}$ with a spectrophotometer (Amresa, Barcelona, Spain).

\section{Enzyme kinetic analysis}

To study the effect of PT-Mm extract on AChE activity, the kinetic analysis of the duodenum AChE solution in the presence of the extract was performed. The mixture of enzyme and PT-Mm (1.5 $\mathrm{mg} / \mathrm{mL})$ was preincubated at $37{ }^{\circ} \mathrm{C}$ for $5 \mathrm{~min}$, and then the substrate in varying concentrations was added and immediately stirred for $10 \mathrm{~s}$. The change 
of absorbance at $412 \mathrm{~nm}$ was monitored and the initial velocity $(\mathrm{dA} / \mathrm{min})$ of the reaction was calculated from the absorbance change. The kinetics of AChE in the presence of PT$\mathrm{Mm}$ was determined by the Lineweaver and Burk (1934) (LB) plot. The LB plot represents the reciprocal velocities substrate concentrations of the control (without inhibitor) and the series of inhibitor concentrations (Trevor, 1981).

\section{Statistical analysis}

Data were analyzed by one-way ANOVA followed by Dennet's t-test using instat (Graph Pad software, USA). A p value of $<0.05$ was considered statistically significant.

\section{RESULTS}

Dose-response effect of PT-Mm on rabbit duodenum

Figure 1 shows the recordings of the mechanical activity of the rabbit duodenum in the presence of PT-Mm. In this study, the different doses of the extract $(40,80,160$ and $200 \mu \mathrm{g} / \mathrm{mL}$ ) showed dose dependent increase on duodenal contractions. The recording obtained at $40 \mu \mathrm{g} / \mathrm{mL}$ showed a no significant $(\mathrm{p}>0.05)$ increase in the amplitude of the spontaneous contractions (Figure 1A). At 80 $\mu \mathrm{g} / \mathrm{mL}$ of PT-Mm, the increase in the amplitude of duodenal contractions was significant $(\mathrm{p}<0.05)$ (Figure $1 \mathrm{~B})$, but it was very significant $(\mathrm{p}<0.01)$ at the dose of 120 $\mu \mathrm{g} / \mathrm{mL}$ of the extract (Figure 1C); while at 200 $\mu \mathrm{g} / \mathrm{mL}$ of PT-Mm the amplitude of contractions reached the maximum (100\%) (P $<0.01$ ) (Figure 1D).

The results presented on Figure 2 showed the dose-response curve of duodenum contractions induced by increasing doses of
PT-Mm. The $\mathrm{EC}_{50}$ was determined from the curve of the amplitude to be $68.57 \pm 4.89$ $\mu \mathrm{g} / \mathrm{ml}$.

Characterization of the active compounds of PT-Mm

Antagonism effect of atropine and PT-Mm on duodenal contractility.

Figure 3 shows the interaction between PT-Mm and increasing concentrations of atropine (muscarinic receptor blocker). The gradual increase in the amplitude of contractions recorded with PT-Mm extract was inhibited significantly $(81.25 \%$ inhibition) by atropine $\left(4.10^{-6} \mathrm{mg} / \mathrm{mL}\right)$.

\section{Antagonism effect of nifedipine and PT-Mm} on duodenal contractility

Figure 4 expresses the interaction between PT-Mm and the varying concentrations of nifedipine (calcium channels blocker). The contractile effect of PT-Mm on spontaneous contractions of duodenal smooth muscle was completely inhibited by nifedipine at $1 \mu \mathrm{g} / \mathrm{mL}$.

Effect of PT-Mm on hydrolytic action of AChE

The kinetic analysis of AChE inhibition by PT-Mm $(40 \mu \mathrm{g} / \mathrm{mL})$ was shown in Figure 5. PT-Mm inhibited AChE in non-competitive manner. The chart of Lineweaver and Burk (1934) in which the lines obtained cross the $\mathrm{Y}$-axis and the $\mathrm{X}$-coordinates in two distinct points which correspond respectively to $1 / \mathrm{Vmax}$ and $-1 / \mathrm{K}_{\mathrm{M}}$ led to the determination of $V \max$ and $\mathrm{K}_{\mathrm{M}}$. The $\mathrm{K}_{\mathrm{M}}$ and $\mathrm{Vmax}$ values for $\mathrm{AChE}$ in the absence of PT-Mm were $578 \mu \mathrm{M}$ and $6664 \mathrm{mM} / \mathrm{min}$, respectively. In the presence of PT-Mm the corresponding values were: $\mathrm{K}_{\mathrm{M}}=578 \mu \mathrm{M}$ and $\mathrm{Vmax}=5687$ $\mathrm{mM} / \mathrm{min}$. 
A. O. GBOKO et al. / Int. J. Biol. Chem. Sci. 6(1): 1-10, 2012

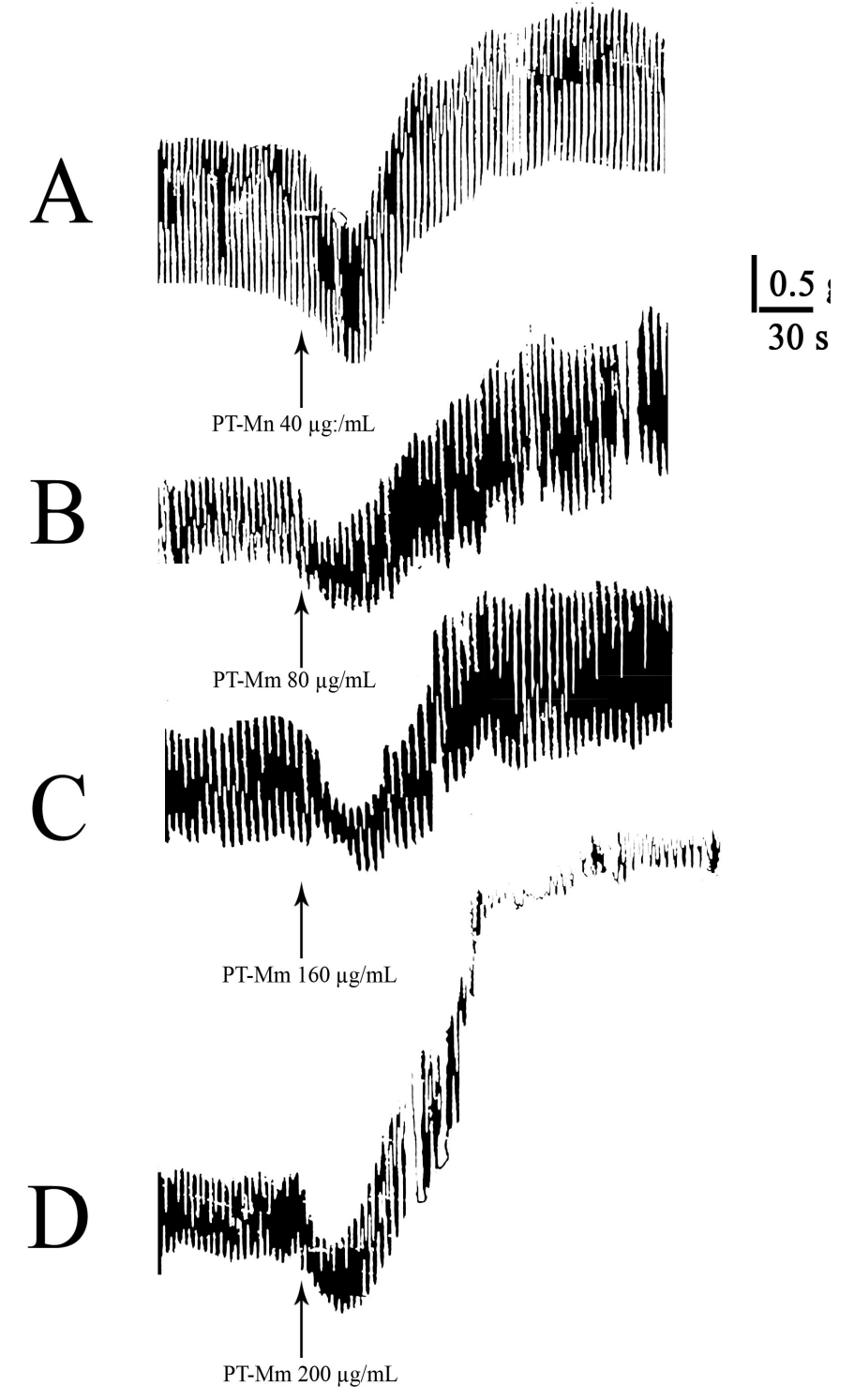

Figure 1: Dose-response effect of PT-Mm rabbit duodenum. 


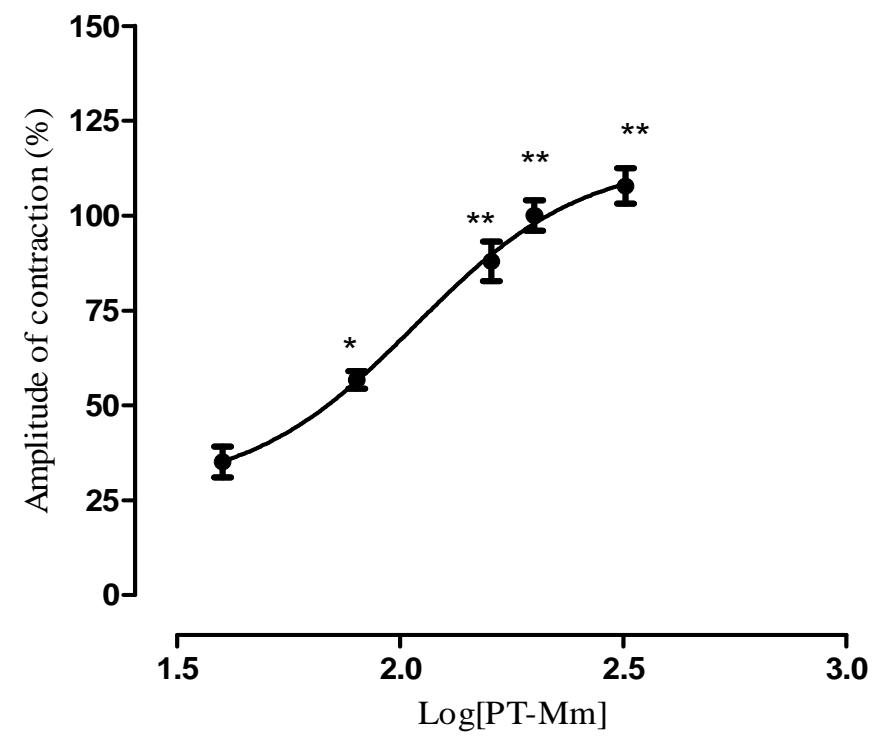

Figure 2: Dose-response curve of graded concentrations of PT-Mm extract on rabbit isolated duodenum. Values are expressed as mean \pm S.E.M $(n=3)$. $*$ P $<$ $0.05 ; * * \mathrm{p}<0.01$ compared to control.

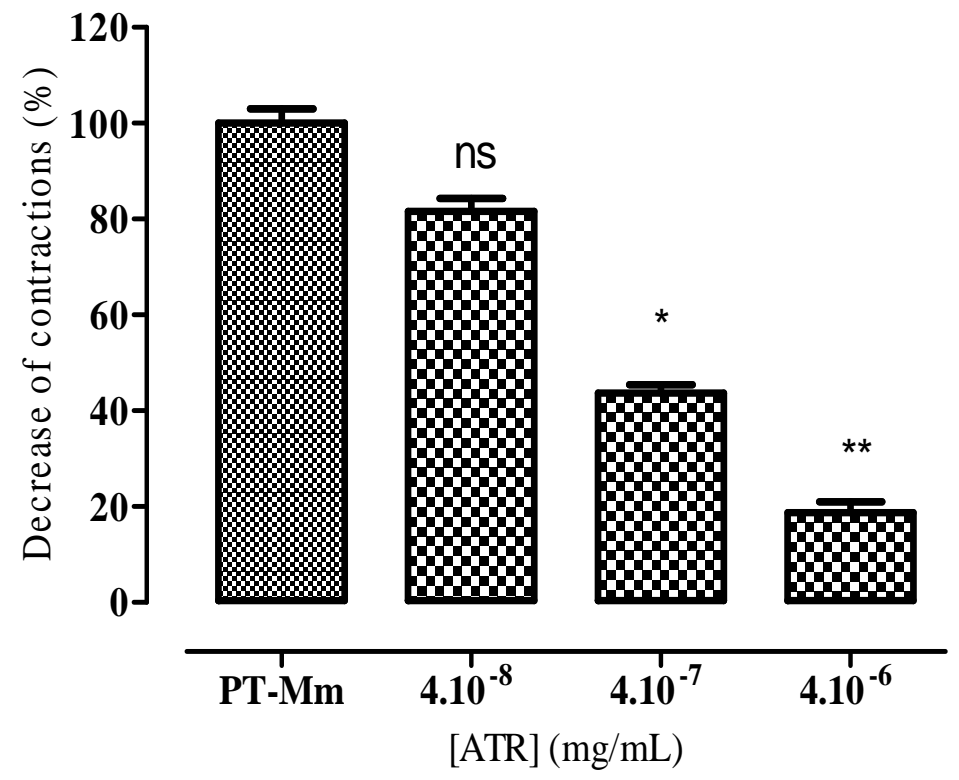

Figure 3: Antagonistic effect of Atropine and PT-Mm extract on the duodenal contractions. Values are expressed as mean \pm S.E.M $(n=3) * \mathrm{P}<0.05 ; * * \mathrm{P}<0.01$ compared to control. 


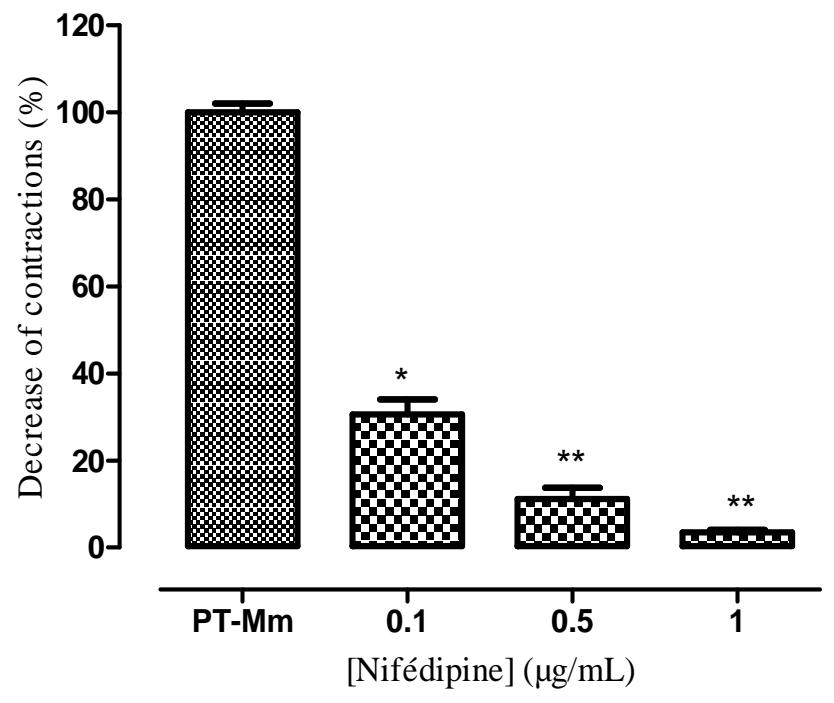

Figure 4: Antagonistic effect of Nifedipine and PT-Mm on the duodenal contractions. Values are expressed as mean \pm S.E.M $(\mathrm{n}=3)$. $* \mathrm{P}<0.05 ; * * \mathrm{P}<0.01$ compared to control.

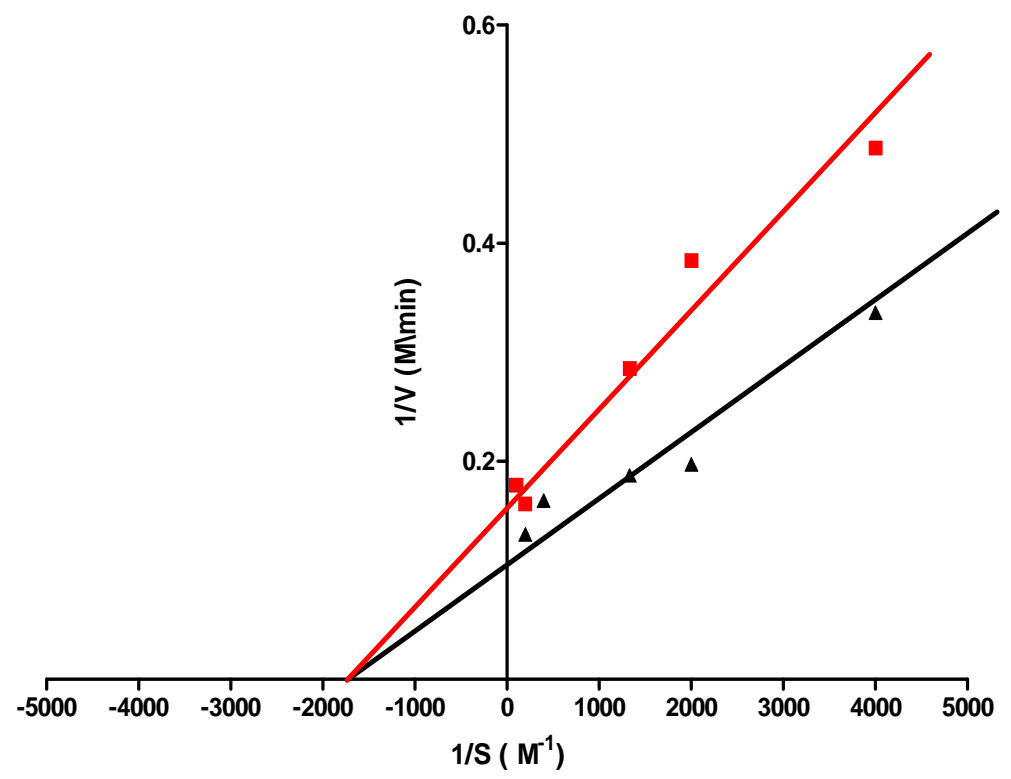

Figure 5: Linewaver-Burk (LB) plot of initial enzyme velocity (V) against the acétylthiocholine iodode concentration ([S]) in the presence ( $\boldsymbol{\Delta})$ and absence ( $\boldsymbol{\square})$ of PT-Mm. 


\section{DISCUSSION}

The leaves Morinda morindoïdes are usually used in folk medicine for the treatment of gastro-intestinal disorders. On the one hand, the pharmacological study of PT-Mm on isolated rabbit duodenum revealed significant and dose-dependent increase in tonicity and amplitude of the spontaneous contractions for varying concentrations (40 and $200 \mu \mathrm{g} / \mathrm{mL}$ ). Similar results were demonstrated with Harpagophytum procumbens on smooth muscle preparations (Mahomed et al., 2005). Furthermore, it is well documented that acetylcholine $(\mathrm{ACh})$ produces spasmogenic effect (Nene-Bi et al., 2009) as PT-Mm on the same muscle. ACh is known to induce contraction by the activation of muscarinic receptors (Naseri and Heidari, 2007) which in turn, increases the intracellular calcium though inositol triphosphate $\left(\mathrm{IP}_{3}\right)$ (Naseri and Heidari, 2007) and also by facilitating the inflow of extracellular calcium though the receptor-operated calcium channel (Zang et al., 2005). The fact that PT-Mm presented myostimulant action as Ach, allowed us to suggest that the plant extract may be contained cholinergic active constituents which would explain its use in the treatment of intestinal diseases.

On the other hand, our results have indicated that, the different concentrations of atropine (an inhibitor of the muscarinic

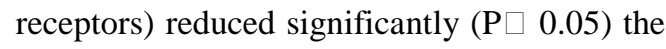
increasing effect of the extract by the decrease of the amplitudes of contraction. Atropine blocked the activation of muscarinic receptors which caused the muscle contraction. This antagonistic test shows the existence of cholinomimetic compounds and precisely muscarinic receptors which are responsible for myostimulant effects in PT-Mm extract. These observations are in concordance with the findings of Goueh et al. (2009) and Meite et al. (2010) on the extracts of and Trema guineensis and Mareya micrantha respectively.

This study had also shown that nifedipine completely inhibited ( $\mathrm{p} \square 0.01$ ) the effect of extract by its calcium channels blocking action. We can say that, when nifedipine blocks calcium channels, the effect of plant extract is inhibited because the smooth muscle contraction (including rabbit duodenum), essentially depends an increase in the cytoplasmic free calcium, which activates the contractile elements. Furthermore the increase in intracellular calcium is due to either influx via voltage-dependent calcium channels or to release from intracellular stores in the sarcoplasmic reticulum (Bashir et al., 2011). Thus, PT-Mm induced its effect though opening calcium channels. This result is similar with the works of Gilani et al. (2007) on Saussured lappa.

In addition to its cholinergic effect, this study demonstrates the inhibition of AChE by PT-Mm. This anticholinesterase activity of PT-Mm corresponds to duodenal contraction. It should be noted that AChE has several peripheral anomeric catalytic sites (Johnson and Moore, 2006).These peripheral sites include the accelerating sites which would be the sites of binding of activators and inhibiting sites which would bind the inhibiting compounds. PT-Mm exerted a noncompetitive inhibiting effect on AChE. These cholinomimetic and anticholinesterase effects are comparable with those of prostigmine and neostigmine which, by inhibiting AChE, increase the peristaltic movement of the intestinal smooth muscle (Krakowsky et al., 1997). This observation agrees with earlier reports (Mahomed et al., 2005; Dodehe et al., 2010) on some biological activities of Harpagophytum procumbens and Combretum molle respectively.

\section{Conclusion}

The results of this work revealed that PT-Mm contains pharmacologically active molecules which exert cholinomimetic and anticholinesterasic effects on duodenal smooth muscle. This physiological activity could support the use PT-Mm extract of Morinda morindoides in the treatment of intestinal disorder. Further research needed to 
fractionate PT-Mm extract and isolate the molecule(s) responsible for the spasmogenic activity observed.

\section{ACKNOWLEDGEMENTS}

The authors wish to thank Pr. Ake Assi of the Department of Botany, University of Cocody- Abidjan, for the botanical identification and collection of the plant.

\section{REFERENCES}

Azam S, Bashir S, Ahmed B. 2011. Antispasmodic action of crude methanolic extract and a new compound isolated from the aerial parts of Myrsine Africana. BMC Complem Altern Med., 11: 55.

Bashir A, Memon R, Gilani AH. 2011. Antispasmodic and antidiarrheal activities of Valeriana hardwickii. Rhizomes are putatively mediated through calcium channel blockade. Evidence-based Complem. Altern. Med., 11: 1-6.

Bosshard W, Dreher R, Schnegg JF, Bula CJ. 2004. The treatment of chronic constipation in elderly people: an update. Drugs Aging., 21: 911-930.

Cimanga RK, De Bruyne T, Hu JP, Cos P, Apers S, Pieters L, Tona L, Kambu K, Vanden BD, Vlietinck AJ. 1999. Constituents form Morinda morindoides leaves as inhibitirs of xanthine, oxydase and scavengers of superoxide anions. Pharm. Pharmacol. Com., 5: 419-424.

Cimanga RK, Hermans N, Apers S, Van Miert $\mathrm{S}$, Vanden $\mathrm{H}$, Claeys $\mathrm{M}$, Pieters L, Vlietinck AJ. 2003. Complementinhibiting iridoids from Morinda morindoides. J. Nat.Prod., 66: 97-102.

Cimanga RK, Kambu K, Tona L, Hermans N, Apers S, Totté J, Pieters L, Vlietinck AJ. 2006. Cytotoxicity and in vitro susceptibility of Entamoeba histolytica to Morinda morindoides leaf extracts and its isolated constituents. J. Ethnopharmacol., 107: 83-90.

Cimanga RK, Muyembe TJJ, Tona LG, Kambu KO, Mesia KG, Apers S, Pieters L, Vlietinck AJ. 2008. Antimalarial activity of some extracts and isolated constituents from Morinda morindoides leaves. J. Nat. Rem., 8(2): 191-202.

Cimanga RK, Mukenyi PNK, Kambu OK, Tona GL, Apers S, Totté JL, Pieters AJ, Vlietinck AJ. 2010. The spasmolytic activity of extracts and some isolated compounds from the leaves of Morinda morindoides (Baker) Milne-Redh. (Rubiaceae). J. Ethnopharmacol., 127: 215-220.

Dawson RMC, Ellit DC, Elliot WH, Jones KM. 1986. Data for biotchemical research, Clarendon Press: Oxford; 537538.

Dodehe Y, Koffi E, Bidié AP, Tako NA, Bahi C, Méité S, Djaman AJ, Guéde-Guina F. 2010. In vitro anticholinesterase and inhibitory effects of the aqueous extract of Combretum molle (Combretaceae) leaf on rabbit breathing. Trop. J. Pharm. Res., 9: 469-473.

Ellman G, Courtne KD, Andress VJ, Featherstone RM. 1961. A new and rapid colorimetric determination of acetylcholinesterase activity. Biochem. pharmacol., 7: 88-95.

Gilani AH, Shah AJ, Yaeesh S. 2007. Presence of cholinergic and calcium antagonist constituents in Saussured lappa explains its use in constipation and spasm. Phytother. Res., 21: 544-1544.

Ginsburg H, Deharo E. 2011. A call for using natural compounds in the development of new antimalarial treatment- an introduction. Malaria J., 10(S1): 1-7.

Goueh G, Jean DN, Ernes K, Flavien T, Frederic G. 2009. In vitro anticholinesterase and cholinergic effect of the aqueory. Trop. J. Pharm. Res., 8: 11-17.

Johnson GL, Moore WL. 2006. l'emplacement anionic peripherique d'acetylcholinesterase: structure, fonction et rôle potentiel dans dessin de la drogue rationnel. Courant dessin pharmaceutique. Bentham. Sci. Ed., 12: 217-225.

Khoa B, Ochillo RF. 1987. Characterisation of cholinesterase of Muscularis muscle of 
bufo marinus. Comp. biochem. Physiol., 87: 107-111.

Krakowsky MD, Mc Gehee DS, Moss J. 1997. Natural inhibitors of cholinesterases: implication for adverse drug reactions. $J$. Can. Anesth., 44(1): 525-534.

Lineweaver H, Burk J. 1934. The determination of enzyme dissociation constants. J. Am. Chem. Soc., 56: 658.

Lowry OH, Rosebrough NJ, Farr AL, Randall RJ. 1951. Protein measurement with the Folin phenol reagent. J. Biol. Chem., 193: 265-275.

Mankele R, Oumba JM, Abena AA, Yal F. 2006. Etude des effets de Morinda morindoides (Back) sur le système immunitaire de l'homme. Phytothér., 2: 68-73.

Mahomed IM, Abdon MN, John AOO. 2005. Pharmacological effects of Harpagophytum Hrocumbens dc [pedaliaceae] secondary root aqueous extract on isolated gastro-intestinal tract muscles of the chick, guinea-pig and rabbit. Afr. J. Trad. CAM., 2(1): 31-45.

Meite S, N'Guessan JD, Bahi C, Yapi HF, Djaman A, Guede-Guina F. 2009. Antidiarrheal activity of the ethyl acetate extract of Morinda morindoides. Trop. J. Pharm. Res., 8: 201-207.

Meite S, Bahi Calixte, Yeo D, Datte JY, Djaman JA, N'guessan DJ. 2010. Laxative activities of Mareya Micrantha (Benth.) Mull. Arg. (Euphorbiaceae) leaf aqueous extract in rats. BMC Complem. Altern. Med., 10: 7.

Mitjans M, Giardia L, Marrero E, Vinardel MP. 2008. Study of ligmed-A, an antidiarrheal drug based on liguin, on rat small intestine enzyme activity and morphometry. J. Vet. Pharmacol. Ther., 24: 349-351.

Muller-Lissner S. (2009). The patholophysiology, diagnosis and treatment of constipation. Dtsch. Artztebl. Int., 106: 424-432.
Naseri MKG, Heidari A. 2007. Antispasmodic effect of Anethum graveolens fruit extract on rat ileum. Int. J. Pharmacol., 3(3): 260-264.

Nene-Bi SA, Traore F, Soro TY, Alain S. 2009. Etudes phytochimique et pharmacologique de Bridelia ferruginea benth (Euphorbiaceae sur la motricité de Taenia coli de cobaye. Afr. Sci., 5: 305320.

N'Guessan JD, Trébissou JND, Bahi C, Guede-Guina F. 2002. Effects de BGG F5 (fraction chromatographique de Morinda morindoides) sur l'activité contractile du coeur isolé de rat. Rev. Ivoir. Sci. Technol., 3: 129-141.

Osterlund B, Janson JC. 1997. A stategic approach to protein purification [Description des strategies de purification, methodes de Management]. Part 1, Pharm. Biotech., 2: 8-10.

Ragone MI, Sella M, Conforti P, Volonte MG, Consolini AE. 2007. The spsmolytic effect of Aloysia citriodora Palace (South American cedrón) is partially due to its vitexin but not isovitexin on rat duodenums. J. Ethnopharmacol., 133: 258-266.

Trevor P. 1981. Undestanding Enzymes, Publisher: west sussex; 97-169.

Wilson K, Walker J 1994. Principles and Techniques of Pratical Biochemistry $\left(4^{\mathrm{e}}\right.$ édn), Cambridge University Press: Oxford.

Zang, WW, Li Y, Wang XQ, Tian F, Cao H, Wang MW, Sun QS. 2005. Effects of magnolol and honokiol derived from traditional chinese herbal remedies on gastro-intestinal movement. World J. Gastroenterol., 11: 4414-4418.

Zihiri GN, Mamb L, Guede-Guina F, Bodo B, Grellier P. 2005. In vitro antiplasmodial activity and cytotoxicity of 33 West African plants used for the treatment of malaria. J. Ethnopharmacol., 98: 281285. 